\title{
Efek Kombinasi Biochar dan Mikoriza pada Pertumbuhan Tanaman Jagung Pulut Ungu (Zea mays L. var ceratina Kulesh) Tanah Inseptisol Reuleut
}

Biochar and Mycorrhiza Applications on Inceptisol Soil in The Development of Purple Waxy Corn (Zea mays L. var ceratina Kulesh)

\author{
Author(s): Rosnina AG ${ }^{(1) *}$; Agung Syafani ${ }^{(1)}$; Adam Supraja ${ }^{(1)}$; Betry $\operatorname{Ardiyanti}^{(1)}$ \\ (1) Universitas Malikussaleh \\ * Corresponding author: rosnina@unimal.ac.id
}

\section{Submitted: 08 Dec 2020}

\begin{abstract}
ABSTRAK
Penelitian ini bertujuan untuk mengetahui pengaruh aplikasi biochar dan pemberian mikoriza pada tanah inseptisol dalam pengembangan tanaman jagung pulut ungu/Dark purple waxy corn (Zea mays L. var ceratina Kulesh). Pada penelitian ini digunakan rancangan acak kelompok (RAK) pola faktorial 3 ulangan yang terdiri dari faktor pemberian biochar (B) terdiri dari $0 \mathrm{t} / \mathrm{ha}, 2 \mathrm{t} / \mathrm{ha}, 4 \mathrm{t} / \mathrm{ha}$ dan faktor mikoriza (M) 0 t/ha, $0.35 \mathrm{t} / \mathrm{ha}, 0.65 \mathrm{t} / \mathrm{ha}$. Data hasil pengamatan dianalisis secara statistik dan apabila berpengaruh nyata dan sangat nyata, maka dilakukan uji lanjut dengan menggunakan Duncan (DMRT). Aplikasi biochar sebagai pembenah tanah yang dapat memperbaiki sifat fisik tanah yang dikombinasikan dengan pemberian fungi mikoriza dan pupuk hayati pada lahan inseptisol dapat meningkatkan pertumbuhan dan tinggi tanaman. Pertumbuhan jagung tertinggi diperoleh pada dosis biochar 2 t/ha. Seiring dengan meningkatnya dosis pupuk biokompos+mikoriza terdapat penurunan tinggi dan kandungan klorofil tanaman jagung pada tanah inseptisol Reuleut.
\end{abstract}

\section{Kata Kunci:}

Biochar;

Mikoriza;

Inseptisol;

Jagung Pulut

Ungu

Keywords: $\quad$ The objective of this study was to determine the effect of biochar and Arbuscular

Biochar; mycorrhiza Fungi (AMF) applications on inceptisol soil in the development of purple waxy corn (Zea mays L. var ceratina Kulesh). This research was

Mycorrhiza; conducted in the experimental garden using Randomized Block Design (RBD)

Inceptisol;

Purple corn. Factorial consisting of a factor of biochar $(B)$ with different doses: 0 t/ha, 2 t/ha, 4 tonnes./ha and mycorrhiza factors $(M)$ with doses $0 \mathrm{t} / \mathrm{ha}, 0.35 \mathrm{t} / \mathrm{ha}, 0.65$ t/ha. The data from the observations were analyzed statistically using Analysis of Variance. The significant differences means existed were separated using Duncan Multiple Range Test (DMRT). The highest growth was possessed by plants applied with biochar 2 t/ha and mycorrhiza 0.65 t/ha. Application of biochar plus AMF ahave improved inceptisol soil characteristics resulted in an increase of plant growth and height. Surprisingly, the overuse of these combinations of ameliorants decreased the plant height and the chlorophyll content. 


\section{PENDAHULUAN}

Jagung (Zea mays) merupakan tanaman jenis serealia yang memiliki kedudukan penting pada sektor ekonomi. Tanaman jagung juga menarik untuk diteliti dalam menjaga kelestraian plasma nutfah. Sebagian masyarakat Indonesia mengkonsumsi jagung sebagai makanan pokok (Riwandi et al. 2014). Daerah Indonesia seperti Madura dan Nusa Tenggara Timur masyarakat pernah menjadikan jagung sebagai makanan pokok (Kementan, 2018).

Saat ini banyak jenis jagung yang telah dikembangkan di Indonesia seperti jagung pulut (Zea mays L. var ceratina Kulesh). Jenis jagung pulut memiliki plasma nutfah yang beraneka warna mulai dari ungu, oranye, kuning, merah, dan hitam. Warna ungu pada jagung pulut ini mengindikasikan komponen bahan aktif seperti $\beta$-karoten, antosianin, dan flavonoid lainnya yang berfungsi sebagai anti oksidan. Komponen antioksidan dapat terjaga, walaupun mengalami penurunan relatif rendah dengan cepatnya masak dalam setiap olahan (Balitsereal, 2019).

Menurut Suarni (2018) jagung pulut yang kini banyak dikembangkan adalah varietas lokal bersari bebas. Jagung pulut lokal Sulawesi memiliki produktivitas mencapai 2-2,5 t/ha, sementara potensi hasil bisa mencapai 8,09 t/ha. Hal ini sejalan dengan Balit Serealia (2019) yang menyatakan bahwa jagung pulut lokal umumnya diusahakan secara tradisional sehingga hasilnya rendah, berkisar 2-3 t/ha, sehingga sulit berkembang dalam skala luas.

Usaha penanaman jagung pulut yang telah dilakukan dengan meningkatkan dosis pupuk anorganik, masih belum dapat meningkatkan hasil yang diperoleh. Hal ini diduga akibat penggunaan pupuk anorganik secara terus menerus tanpa dibarengi dengan pemberian bahan organik yang dapat merusak sifat fisik, dan biologi tanah yang menyebabkan produktivitas lahan menurun (Yusnaini, 2009).

Upaya dalam mengatasi dan meningkatkan produktivitas lahan dan hasil jagung selain dengan penambahan bahan organik juga dengan pemberian amelioran dan pupuk biokompos sebagai pembenah tanah seperti arang sekam padi (biochar) yang dapat memperbaiki sifat fisika, kimia dan biologi tanah sehingga pemberian pemupukan lebih efektif dan efisien dalam meningkatkan hasil tanaman jagung pulut. Disamping pemberian bahan pembenah tanah terutama pada tanah pada lahan kering seperti tanah inseptisol perlu dilakukan penggunaan mikroba-mikroba seperti mikoriza yang dapat meningkatkan penyerapan nutrisi terutama unsur phosfor sebagai unsur hara makro yang digunakan oleh tanaman. Aplikasi biochar dan biokompos akan meningkatkan kehidupan biota dan mikroorganisme tanah yang berperan dalam mendekomposisi bahan organik dalam menyediakan unsur hara bagi tanaman.

Biochar arang sekam adalah hasil proses pembakaran secara parsial, merupakan arang hayati berpori yang berasal dari limbah sekam padi. Seperti yang dikemukakan oleh Santi dan Goenadi (2016), biochar dihasilkan melalui proses pembakaran biomass namun tidak sampai menjadi abu. Hasil penelitian Situmeang dan Sudewa, (2013) menunjukan bahwa pengaplikasian biochar dapat meningkatkan berat basah tanaman dan berat kering oven tanaman. Lebih lanjut Situmeang et al., (2016) mengemukakan pemberian biochar 5-10 t/ha dan dosis kompos 7,7-15 t/ha dapat meningkatkan tinggi tanaman, berat segar tongkol, dan berat segar berangkasan tanaman jagung.

Aplikasi mikoriza merupakan suatu bentuk asosiasi saling menguntungkan antara hifa fungi mikoriza dengan cara menginfeksi akar tanaman sehingga 
mengakibatkan memperluas zona perakaran yang dapat meningkatkan jumlah penyerapan hara dalam meningkatkan pertumbuhan dan perkembangan tanaman. (Hanafiah, et al., 2009) melaporkan bahwa hifa mikoriza mampu berasosiasi dengan hampir $90 \%$ jenis tanaman dalam meningkatkan efisiensi penyerapan hara, fosfor $(\mathrm{P})$ terutama pada lahan marginal. Hasil penelitian Ramadhan et al.,(2015) menunjukkan akar tanaman yang terinfeksi dengan hifa mikoriza tumbuh lebih baik dari pada yang tidak terinfeksi. Perkembangan hifa mikoriza dapat memperluas zona perakaran sehingga dapat menjangkau hara keberadaan unsur hara dan meningkatkan penyerapan unsur hara makro terutama unsur P dan beberapa unsur hara mikro. Lebih lanjut (Musafa, et al. (2017) menyatakan bahwa aplikasi mikoriza pada penanaman jagung di tanah Inseptisol mampu meningkatkan Phosfor yang tersedia sebanyak 16,94 ppm.

Penelitian ini bertujuan untuk mengetahui aplikasi biochar dan mikoriza yang optimal terhadap pertumbuhan dan peningkatan produksi jagung lumut ungu pada tanah inseptisol.

\section{METODOLOGI}

Penelitian ini dilaksanakan di kebun percobaan dan Lab. Tanah Fakultas Pertanian Universitas Malikussaleh.

Bahan yang digunakan dalam penelitian ini adalah biochar, mikoriza, pupuk biokompos sebagai pupuk dasar dan benih jagung pulut ungu. Alat yang digunakan adalah, meteran, cangkul, garu, parang babat, water sprinkle, timbangan digital, jangka sorong, ember, gunting, penggaris, alat tulis, dan kamera.

Penelitian ini dilakukan dengan menggunakan rancangan acak kelompok (RAK) faktorial yang terdiri dari:

1. Faktor pemberian biochar disimbol dengan $\mathrm{B}$ terdiri dari:

$$
\mathrm{B}_{0}: 0 \mathrm{t} / \mathrm{ha}
$$

$$
\begin{aligned}
& \mathrm{B}_{1}: 2 \mathrm{t} / \mathrm{ha} \\
& \mathrm{B}_{2}: 4 \mathrm{t} / \mathrm{ha}
\end{aligned}
$$

2. Faktor pemberian mikoriza disimbol dengan $\mathrm{M}$ terdiri dari:

$$
\begin{aligned}
& \mathrm{M}_{0}: 0 \mathrm{t} / \mathrm{ha} \\
& \mathrm{M}_{1}: 0.35 \mathrm{t} / \mathrm{ha} \\
& \mathrm{M}_{2}: 0.65 \mathrm{t} / \mathrm{ha}
\end{aligned}
$$

Dengan demikian diperoleh 9 kombinasi perlakuan dengan 3 ulangan sehingga terdapat 27 satuan percobaan.

Pemberian biochar dilakukan dengan cara menaburkannya di atas permukaan bedeng sesuai dosis yang telah ditetapkan. Sementara aplikasi mikoriza dilakukan dengan masingmasing dosis $5 \mathrm{~g}, 10 \mathrm{~g}$ dan $15 \mathrm{~g}$ per bedeng. Pengamatan terhadap efek pemberian mikoriza pada akar dilakukan dengan cara akar dibersihkan dan dibias dengan dengan aquadest kemudian direndam dengan larutan $\mathrm{KOH} 10 \%$ selama 24 jam, selanjutnya akar yang bewarna putih di cuci lagi dengan aquadest dan direndam dalam larutan HCL $2 \%$ selama 24 jam, pada hari selanjutnya dibilas dengan aquadest dan direndam dalam larutan Tripan blue 0,05\% selama 24 jam. Untuk pengamatan total infeksi dilakukan dengan cara mengambil 10 potongan akar yang sudah direndam dengan Tripan blue $0,05 \%$ dan ukuran panjang akar $1 \mathrm{~cm}$ yang telah dipotong, kemudian diamati dibawah mikroskop dengan perbesaran 400 magnifikasi. Akar yang terinfeksi ditandai dengan terdapatnya hifa, arbuskular dan vesicular

Pengukuran terhadap jumlah klorofil dilakukan dengan menggunakan klorofil meter. Pengambilan data dilakukan secara acak pada 3 bagian permukaan daun, kemudian dirata-ratakan. Pelaksanaannya dilakukan pada jam 10 sd jam 11 siang.

Data hasil pengamatan dianalisis secara statistik dan apabila berpengaruh nyata dan sangat nyata, maka dilakukan uji lanjut dengan menggunakan Duncan (DMRT) pada taraf 5\%. 
HASIL DAN PEMBAHASAN

Pengaruh Aplikasi Biochar dan Mikoriza pada Pertumbuhan Tanaman Jagung

Biochar atau disebut arang hayati merupakan materi padat yang terbentuk dari karbonisasi biomasa. Penambahan biochar ke tanah meningkatkan ketersediaan kation utama, fosfor, $\mathrm{N}$ total dan kapasitas tukar kation tanah yang pada akhirnya meningkatkan hasil karena dapat mengurangi risiko pencucian hara khususnya kalium dan $\mathrm{N}-\mathrm{NH}_{4}$ (Bambang, 2012). Lebih lanjut Rostaliana et al. (2013), menyatakan pemanfaatan biochar 12 t/ha memberikan pengaruh nyata terhadap peningkatan kualitas tanah, yaitu berat volume dan $\mathrm{K}$ tersedia, selain itu juga berpengaruh nyata terhadap tinggi tanaman jagung.

Menurut Situmeang \& Sudewa, (2013) pengaplikasian biochar dapat meningkatkan tinggi tanaman, jumlah daun, dan luas daun per tanaman. Meningkatnya jumlah daun dan luas daun dapat meningkatkan laju pertumbuhan dan perkembangan tanaman, karena jumlah cahaya yang dapat di intersepsi dalam proses fotosintesis untuk membentuk bahan kering tanaman akan semakin meningkat. Asimilat yang terbentuk sebagai hasil dari proses fotosintesis akan digunakan untuk pembentukan sel-sel baru dalam proses pertumbuhan dan perkembangan organ-organ vegetatif tanaman.

Pengaplikasian mikoriza mampu meningkatkan P-tersedia hingga 29\% dan meningkatkan C-organik hingga 49\% dibanding kontrol. Peningkatan ketersediaan hara dipengaruhi oleh mikroba tanah yang berperan dalam mempercepat dekomposisi bahan organik dan sebagai pemicu tingkat kelarutan senyawa anorganik yang tidak tersedia menjadi bentuk tersedia bagi tanaman.
Tabel 1. Pengaruhi aplikasi Biochar dan Mikoriza pada pertumbuhan tanaman jagung

Table 1. The effects of Biochar and Mycorrhiza application on the growth of maize

\begin{tabular}{lllr}
\hline $\begin{array}{c}\text { Rasio } \\
\text { Biochar:Mikoriza } \\
\text { (t/ha) }\end{array}$ & Tinggi & $\sum$ Daun & $\sum$ Klorofil \\
\hline $0: 0$ & $24,70 \mathrm{c}$ & $3,67 \mathrm{~b}$ & $8,22 \mathrm{a}$ \\
\hline $0: 0,35$ & $35,63 \mathrm{a}$ & $4,87 \mathrm{a}$ & $16,78 \mathrm{a}$ \\
\hline $0: 0,65$ & $27,23 \mathrm{bc}$ & $4,13 \mathrm{ab}$ & $9,13 \mathrm{a}$ \\
\hline $2: 0$ & $35,63 \mathrm{a}$ & $5,27 \mathrm{a}$ & $13,64 \mathrm{a}$ \\
\hline $2: 0,35$ & $36,60 \mathrm{a}$ & $4,93 \mathrm{a}$ & $16,22 \mathrm{a}$ \\
\hline $2: 0,65$ & $37,46 \mathrm{a}$ & $4,87 \mathrm{a}$ & $15,86 \mathrm{a}$ \\
\hline $4: 0$ & $35,70 \mathrm{a}$ & $4,73 \mathrm{ab}$ & $13,88 \mathrm{a}$ \\
\hline $4: 0,35$ & $31,83 \mathrm{abc}$ & $4,33 \mathrm{ab}$ & $11,87 \mathrm{a}$ \\
\hline $4: 0,65$ & $32,73 \mathrm{ab}$ & $4,47 \mathrm{ab}$ & $12,66 \mathrm{a}$ \\
\hline
\end{tabular}

Data pada Tabel 1. terlihat data pemberian biochar sebanyak $1,2 \mathrm{~kg} / \mathrm{plot}$ (B1) atau setara dengan 2 t/ha dan mikoriza $400 \mathrm{~g} /$ plot (M2) setara dengan 0,65 t/ha, merupakan kombinasi dan jumlah pembenah tanah yang optimal dalam meningkatkan pertumbuhan tertinggi tanaman jagung pulut ungu yaitu $37.46 \mathrm{~cm}$ yang ditanam pada lahan inseptisol Reuleut ini, memiliki selisih yang nyata dengan tinggi tanaman jagung terendah $(24.70 \mathrm{~cm})$ pada blok kontrol. Lahan inseptisol dikenal sebagai lahan kering yang memiliki $\mathrm{pH}$ masam yang dapat menyebabkan tingginya ion $\mathrm{Al}$, Fe dan $\mathrm{Mn}$ yang mudah mengikat hara phosfor dimana ketersediaan haranya terbatas sehingga tidak dapat diserap oleh tanaman menyebabkan pertumbuhan tanaman jagung pulut mengalami kekerdilan. Sukar diharapkan pertumbuhan tanaman secara optimal tanpa pemberian bahan pembenah tanah yang dapat memperbaiki karakteristik tanah dan membantu ketersediaan dan daya serap unsur hara tanaman.

Biochar sebagai bahan amelioran dapat meningkatkan porositas dan tanah menjadi gembur sehingga hifa fungi mikoriza dapat berpenetrasi dengan leluasa dalam menginfeksi dan memperluas zona perakaran yang dapat meningkatkan serapan hara makro seperti nitrogen dan fosfor yang dibutuhkan 
dalam pertumbuhan vegetatif tanaman jagung pulut yang berpengaruh nyata terhadap tinggi tanaman jagung seperti yang terlihat pada Gambar 1.



Gambar.1. Perbandingan pertumbuhan jagung pada tanah yang diaplikasi Biochar Mikoriza (A), dan tanpa biochar (B).

Figure 1. The comparison of maize growth on the soil biochar mycorrhiza application (A), and control (B).

Senada dengan Santi \& Goenadi, (2016) yang mengemukakan aktivitas mikroba dalam tanah dapat meningkat dengan pemberian biochar, sebagai pembenah tanah yang dapat memperbaiki sifat fisik tanah diantaranya memperbaiki agregat tanah, porositas tanah dan konsistensi melalui perubahan luas permukaan serta distribusi ruang pori, kerapatan dan kemampatan, sehingga dapat menyediakan lingkungan ideal untuk aktivitas dan perkembangan fungi mikoriza.

Pemberian kombinasi biochar 1,2 $\mathrm{kg} /$ plot (B1) tanpa Mikoriza $0 \mathrm{~g} / \mathrm{plot}$ (M0) mampu meningkatkan jumlah daun pada tanaman jagung pulut ungu. Ratarata jumlah daun maksimum didapat 5,27 helai yang menunjukkan beda nyata dengan perlakuan tanpa penambahan biochar dan mikoriza yang memiliki jumlah daun 3,7 helai.

Hasil analisis statistik terhadap kandungan klorofil menunjukkan bahwa kombinasi perlakuan biochar $1,2 \mathrm{~kg} / \mathrm{plot}$ (B1) atau setara dengan $2 \mathrm{t} / \mathrm{ha}$ dan mikoriza $200 \mathrm{~g} /$ plot (M1) atau setara 0,35 t/ha cenderung memberikan kandungan klorofil 16,22 CCI yang tidak berbeda nyata dengan dosis terendah biochar 0 g/plot (B0) dan mikoriza (M0) $0 \mathrm{~g} / \mathrm{plot}$ yaitu 8,22 CCI. Berdasarkan data pertumbuhan tinggi tanaman dan pencatatan terhadap kandungan klorofil terdapat kecenderungan penurunan tinggi tanaman dan jumlah klorofil yang cenderung menurun seiring dengan penambahan dosis pemberian biochar dan aplikasi mikoriza.

\section{Pengaruh Mikoriza terhadap Bulu-bulu Akar}

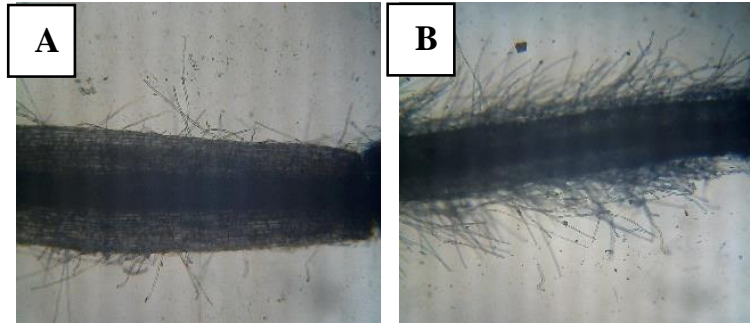

Gambar 2. Perbandingan kondisi perakaran tanaman jagung, (A) tanpa mikoriza, (B) terinfeksi mikoriza.

Figure 2. The comparison of the maize root conditions, (A) control, (B) infected by mycorrhiza.

Berdasarkan Gambar 2. Dapat kita lihat bahwa akar tanaman yang ditanam yang aplikasi mikoriza memiliki lebih banyak bulu-bulu akar dibandingkan dengan akar tanaman tanpa mikoriza (kontrol). Bulu-bulu akar berfungsi untuk menyerap unsur-unsur hara dari tanah dan menjadikannya tersedia bagi tanaman. Selain itu mikoriza juga mampu menstimulir hormon pertumbuhan tanaman, seperti sitokinin dan auksin yang berperan dalam pembelahan dan pemanjangan sel. Dengan bertambahnya bulu-bulu akar maka jumlah unsur hara yang tersedia berimplikasi pada hasil tanaman yang lebih tinggi. Tidak demikian halnya pertumbuhan bulu akar pada tanaman kontrol yang lebih sedikit berdampak pada hasil yang rendah. Musafa et al., (2017) menyatakan bahwa hifa fungi mikoriza berasosiasi dengan akar tanaman yang dapat meningkatkan penyerapan hara yang sehingga 
mempercepat laju pertumbuhan jagung sebesar $28 \%$.

Hal yang sama dikemukakan oleh (Nafiah, 2019) bahwa aplikasi mikoriza pada budidaya tanaman jagung dapat meningkatkan tinggi tanaman hingga $34 \%$. Peningkatan tinggi tanaman tersebut diakibatkan oleh keberadaan mikoriza yang terkandung di dalam pupuk hayati. Selain itu mikoriza mampu memperluas zona perakaran dari tanaman yang terinfeksi sehingga dapat menyerap unsur hara lebih optimal terutama unsur hara $\mathrm{P}$ sehingga dapat tersedia untuk tanaman.

\section{KESIMPULAN}

1. Aplikasi biochar sebagai pembenah tanah yang dapat memperbaiki sifat fisik tanah yang dikombinasikan dengan pemberian fungi mikoriza dan pupuk hayati pada lahan inseptisol dapat meningkatkan pertumbuhan dan tinggi tinggi tanaman.

2. Terdapat pertambahan tinggi dan jumlah klorofil seiring dengan penambahan dosis yang diberikan pada tanah inseptisol Reuleut.

\section{DAFTAR PUSTAKA}

Balitsereal. (2019). Jagung Pulut untuk 钢 Diversifikasi Pangan.

Bambang, S. A. (2012). Si hitam biochar 理 yang multiguna. PT. Perkebunan Nusantara X (Persero), Surabaya.

Hanafiah, A. S., Sabrina, T., \& Guchi, H. EQ (2009). Biologi dan Ekologi Tanah. Universitas Sumatera Utara. Medan, 184.

Kementan. (2018). Komoditas Pertanian Sub Sektor Tanaman Pangan. Pusat Data Dan Sistem Informasi Pertanian, Kementerian Pertanian. Jakarta.

Musafa, M. K., Aini, L. Q. L. Q., \& 的 Prasetya, B. (2017). Peran mikoriza arbuskula dan bakteri Pseudomonas fluorescens dalam meningkatkan serapan $\mathrm{P}$ dan pertumbuhan tanaman jagung pada andisol. Jurnal Tanah Dan Sumberdaya Lahan, 2(2), 191197.

Nafiah, B. I. (2019). Pengaruh Pupuk El Hayati Konsorsium Mikroba danMikoriza Arbuskular terhadap Pertumbuhan Tanaman Jagung pada Inceptisols. Universitas Brawijaya.

RAMADHAN, R. (n.d.). STUDI PERTUMBUHAN TANAMAN TEBU TOLERAN CEKAMAN AIR BERDASARKAN KARAKTER FISIOLOGISNYA. In repository.unej.ac.id.

Riwandi, R., Merakati, H., \& Hasanudin, 县 H. (2014). Teknik Budidaya Jagung dengan Sistem Organik Di Lahan Marjinal. UNIB Press.

Rostaliana, P., Priyono, P., \& Edhi, T. (2013). Pemanfaatan Biochar untuk Perbaikan Kualitas Tanah dengan Indikator Tanaman Jagung Hibrida dan Padi Gogo pada Sistem Lahan Tebang Bakar. Fakultas Pertanian UNIB.

SANTI, L. P., \& GOENADI, D. H. (2016). Pemanfaatan bio-char sebagai pembawa mikroba untuk pemantap agregat tanah Ultisol dari Taman Bogo-Lampung The use of bio-char as bacterial carrier for aggregate stabilization in Ultisol Soil from Taman Bogo-Lampung. EJournal Menara Perkebunan, 78(2).

Situmeang, Y. P., \& Sudewa, K. A. 㰯 (2013). Respon Pertumbuhan Vegetatif Tanaman Jagung Pulut pada Aplikasi Biochar Limbah Bambu.

Situmeang, Y. P., Sudewa, K. A., Suarta,

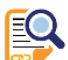


M., \& Risa Andriani, A. A. S. (2016). Biochar and Compost Effect on the Growth and Yield of Sweet Corn. Gema Agro, 16(36), 16-19.

Suarni, S., \& others. (2018). 期 Pengembangan Pangan Tradisional Berbasis Jagung Mendukung Diversifikasi Pangan.

Yusnaini, S. (2009). Keberadaan Mikoriza EQ Vesikular Arbuskular pada Pertanaman Jagung yang Diberi Pupuk Organik dan Inorganik Jangka Panjang. Journal of Tropical Soils 1, 14(3), 253-260. 